\title{
Habitat patches that cross marine reserve boundaries: consequences for the lobster Jasus edwardsii
}

\author{
Debbie J. Freeman ${ }^{1,3, *}$, Alison B. MacDiarmid ${ }^{2}$, Richard B. Taylor ${ }^{1}$ \\ ${ }^{1}$ University of Auckland, Leigh Marine Laboratory, PO Box 349, Warkworth 0941, New Zealand \\ ${ }^{2}$ National Institute of Water and Atmospheric Research, PO Box 14901, Kilbirnie, Wellington 6241, New Zealand \\ ${ }^{3}$ Present address: Department of Conservation, Research and Development Group, PO Box 10-420, Wellington 6143, \\ New Zealand
}

\begin{abstract}
The spatial configuration of marine reserves should reflect management objectives. If reserves are intended to conserve 'natural' biological communities, then reserve boundaries should follow barriers to species movement, but if cross-boundary movement of harvestable individuals associated with certain habitat is desired for fisheries purposes, then boundaries should intersect that habitat. We relate movement patterns of the reef-associated spiny lobster Jasus edwardsii (Palinuridae) to the relative positions of habitat and reserve boundaries in a $24.5 \mathrm{~km}^{2}$ marine reserve on the temperate northeast coast of New Zealand by tagging $>5000$ individuals and recapturing a subset over 3 yr using pots. Lobster movement patterns were sex- and size-dependent, but nearly all recaptured individuals were found on the same rocky reef on which they were tagged, indicating that lobsters were reluctant to cross the muddy sediments between reefs. Lobsters became increasingly likely to migrate from the reserve into the heavily fished adjacent coast as the proportion of their reef that was unprotected increased. Corresponding changes in average catch per unit effort (CPUE) and size of all lobsters (tagged and untagged) occurred within the protected parts of the reefs, with lobster densities on a fully protected reef being 8-fold higher than densities on the protected part of a reef that was $91 \%$ unprotected.
\end{abstract}

KEY WORDS: Exploited species $\cdot$ Habitat boundary $\cdot$ Tag-recapture $\cdot$ Marine protected areas Resale or republication not permitted without written consent of the publisher

\section{INTRODUCTION}

Marine reserves are often intended to conserve populations living within them at natural densities while simultaneously providing a source of harvestable individuals to the adjacent fishery through cross-boundary movement (Halpern \& Warner 2003). These goals are compatible if movement from the reserve represents excess individuals forced to emigrate due to insufficient resources or behavioural pressures (Abesamis \& Russ 2005). However, the goals potentially conflict where high emigration rates thwart the conservation objective of full recovery, or where low emigration rates of harvestable individuals provide negligible benefits for the adjacent fishery. The degree to which a given species will be protected within a reserve versus made available to the adjacent fishery depends on the configuration of the reserve relative to the movement patterns of individuals (Edgar \& Barrett 1999, Jennings 2000). Many species are strongly associated with a particular habitat, so individuals living on habitat patches that cross reserve boundaries should be more likely to enter adjacent unprotected areas than individuals living on patches insulated from reserve boundaries by natural barriers in the form of unsuitable habitat (Kramer \& Chapman 1999). Recent research, mostly on reef fishes, has confirmed that export from reserves is usually greater when habitat patches cross reserve boundaries (Tewfik \& Bene 2003, Topping et al. 2005, Tupper 2007, Forcada et al. 2009), but to our knowledge, the consequence of the loss of individuals for the population remaining inside the reserve and how this 
relates to the proportion of habitat patches exposed to fishing has not been documented for any species.

The spiny lobster Jasus edwardsii (Hutton, 1875) (Palinuridae) is common on temperate rocky reefs around New Zealand and southern Australia. It is heavily fished in most regions and typically increases in size and abundance when protected within no-take marine reserves (Edgar \& Barrett 1999, Kelly et al. 2000). In northeastern New Zealand, its recovery in marine reserves appears to have contributed to shifts in rocky reef community structure (Babcock et al. 1999, Shears \& Babcock 2002). J. edwardsii undertake seasonal inshore-offshore movements that can exceed $5 \mathrm{~km}$ and are associated with moulting and reproduction (MacDiarmid 1991, Booth 1997, Kelly 2001, Gardner et al. 2003, Kelly \& MacDiarmid 2003). Smaller lobsters tend to move further than larger lobsters (MacDiarmid et al. 1991, Kelly \& MacDiarmid 2003).

We determined how the spatial relationship between habitat patches and reserve boundaries affects the spiny lobster Jasus edwardsii within and adjacent to the fully-protected Te Tapuwae o Rongokako Marine Reserve in temperate northeastern New Zealand. This $24.5 \mathrm{~km}^{2}$ reserve was established in November 1999 and average densities of legal-sized ( $\geq 54 \mathrm{~mm}$ tail width for males, $\geq 60 \mathrm{~mm}$ tail width for females) lobsters within it have since increased from 20 ind. ha ${ }^{-1}$ in 2000 to 180 ind. ha ${ }^{-1}$ in 2005, while densities outside have remained at $<40$ ind. ha ${ }^{-1}$ (D. J. Freeman unpubl. data). The reserve protects 3 large continuous rocky reefs separated by muddy sediments that lobsters rarely cross (see 'Results'). One reef lies entirely within the reserve boundaries, while 60 and $91 \%$ of the areas of the other 2 reefs are unprotected. Since lobsters outside the reserve are heavily fished (Haist et al. 2005), we predicted that as the unprotected proportion of a reef increased, (1) the rate of emigration of lobsters from the protected part of the reef to the adjacent fished part would increase, and (2) densities of individuals on the protected part of the reef would decrease, as would average sizes of lobsters. We tested these predictions by tagging 5225 individuals throughout the protected portions of the 3 reefs. We conducted pot surveys seasonally over 3 yr to recapture tagged lobsters and to quantify the abundance, distribution and movement patterns of lobsters in relation to habitat and marine reserve boundaries.

\section{MATERIALS AND METHODS}

Study site. Te Tapuwae o Rongokako Marine Reserve, on the east coast of the North Island of New Zealand (see Fig. 3), was established in November 1999 and protects $24.5 \mathrm{~km}^{2}$ of coastline, extending up to $5 \mathrm{~km}$ offshore to a depth of nearly $50 \mathrm{~m}$. The entire area is closed to all forms of fishing. The distribution of reefs and associated biodiversity were previously mapped using remote video camera and sidescan sonar (Wilson et al. 2007). The reserve entirely encompasses Pariokonohi Reef and also includes portions of reefs near the southern and northern reserve boundaries. At the northern end of the reserve, approximately $40 \%$ of Whangara Reef is contained within the reserve; at the southern end of the reserve, approximately $9 \%$ of Turihaua Reef is contained within the reserve. North of Whangara Reef, B5 Reef lies entirely outside the reserve. The 4 reefs have similar areas (5 to $6 \mathrm{~km}^{2}$ ), depth ranges (intertidal to approximately $40 \mathrm{~m}$ ), geologies (all sandstone or siltstone), and exposures to wave action (all face southeast). They also support similar assemblages, with mixed brown algal assemblages dominating the shallow subtidal, Ecklonia radiata forest to approximately $20 \mathrm{~m}$, and encrusting invertebrates (predominantly sponges) beyond this (D. J. Freeman pers. obs.). The understory beneath the kelp forest is comprised of coralline and foliose algae, with a range of mobile invertebrates (including sea urchins Evechinus chloroticus) and encrusting invertebrates (Shears \& Babcock 2004).

Tagging. To describe the movement patterns of spiny lobsters Jasus edwardsii within and surrounding Te Tapuwae o Rongokako Marine Reserve, 5225 individuals were tagged within the reserve, mostly during November and December 2003. The tagged lobsters included 3785 males $(58.1 \pm 0.1 \mathrm{~mm}$ tail width, all values are mean $\pm \mathrm{SE})$ and 1440 females $(53.9 \pm 0.1 \mathrm{~mm})$. Lobsters were tagged using T-bar anchor tags (Hallprint Pty), inserted dorsally between the first and second abdominal segments, either side of the centre line to avoid the intestine and as close to the tail as possible to avoid the body cavity. Each tag was individually numbered, with a short length at the distal end of the tag remaining free from text, to act as a buffer against chew-damage from conspecifics. Every tagged lobster, with the exception of egg-bearing females, also had the distal third of 1 pleopod clipped using scissors, to enable the detection of tag loss and moulting (the latter indicated by a partially regrown pleopod). After tagging, lobsters were immediately returned to the sea as close as possible to their capture location.

Data recorded for every tagged lobster included tail width (measured with vernier callipers to the nearest $0.1 \mathrm{~mm}$ in a straight line between the tips of the primary spines on the second segment of the tail) and sex. We aimed to tag representatives of the range of sizes of lobster available within and surrounding the marine reserve.

This study was advertised and reported on in local newspapers and magazines, and divers and fishermen were asked to record the tag number, sex, tail width 
and location of any tagged lobster they observed or caught. Tag reporting forms were provided to all commercial fishermen working in the vicinity of the study site and to members of the public upon request. No reward was offered for providing recapture reports, but fishermen were allowed to keep tagged legal-sized lobsters caught outside the marine reserve.

Pot surveys. Lobsters were captured for scientific reserch purposes by means of permitted commercial fishing vessels using lobster pots both within Te Tapuwae o Rongokako Marine Reserve and adjacent fished areas. Sampling was undertaken approximately every 3 mo beginning in November 2003 and ending in November 2006, with 134 to 294 pot lifts completed during each sampling event within the reserve, and 15 to 134 pot lifts outside the reserve (3168 total, Table 1). Pots were primarily standard $52 \mathrm{~mm}$ mesh pots, used widely in the New Zealand commercial lobster fishery. A number of three-quarter-sized pots were also used, mainly in winter 2004. These were also 52-mm mesh, but were three-quarters of the width of the standard pots and were easier to handle on the vessels available during this period. The location and number of pots set depended on weather and sea conditions, the vessel used, and the presence of other fishing gear. Where possible, reef habitat from a range of depths throughout the marine reserve and within approximately $3 \mathrm{~km}$ of the reserve's boundary was sampled in order to obtain tag recaptures. We aimed to avoid bias relating to variation in sampling effort, which could have resulted in an apparent directionality of dispersion of tagged animals (Annala \& Bycroft 1993, Rowe 2001) or prevented detection of movement (Davis \& Dodrill 1989, Hilborn 1990). Pot locations were recorded ( $\pm \sim 30 \mathrm{~m}$ ) using a Garmin Etrex GPS. Tail width and sex were recorded for every lobster captured. Individuals $<54 \mathrm{~mm}$ tail width were excluded from analyses because they are not reliably sampled using the pots.

Table 1. Jasus edwardsii. Number of pot lifts completed inside and outside Te Tapuwae o Rongokako Marine Reserve ('Reserve' and 'Fished,' respectively)

\begin{tabular}{|clcc|}
\hline Date & Reserve & Fished \\
\hline 2003 November & 134 & 15 \\
December & 294 & 90 \\
2004 February & 183 & 18 \\
June & 171 & 44 \\
August & 164 & 27 \\
November & 201 & 134 \\
2005 March & 186 & 64 \\
May & 173 & 75 \\
November & 151 & 54 \\
2006 February & 182 & 63 \\
May & 170 & 80 \\
September & 165 & 80 \\
November & 166 & 84 \\
\hline
\end{tabular}

\section{RESULTS}

Of the 5225 lobsters tagged in the reserve, 921 were recaptured at least once. The mean tail width of recaptured tagged males within the reserve was $59.6 \pm$ $4.4 \mathrm{~mm}$ and the mean size for females was $57.5 \pm$ $4.8 \mathrm{~mm}$. The majority of tagged lobsters were recaptured during our regular pot surveys, but 42 individual tagged lobsters were reported (from outside the marine reserve, some more than once) by commercial and recreational fishermen. Of these, 25 were kept as catch. An additional record supplied by fishermen was excluded from the analysis, as it involved a large movement and unrealistic reduction in tail width over time. A further recapture recorded during our pot surveys was excluded from the analysis as it involved a change in sex. The reporting rate by fishermen could not be estimated in our study, but has been suggested to be low (0.2 to 0.23 ) and temporally variable in other Jasus edwardsii fisheries (Frusher \& Hoenig 2001a). We have assumed that fishermen's reporting rates outside the reserve were unbiased with respect to reef origin.

Some tagged lobsters moved more than $4 \mathrm{~km}$ from their initial release locations, but most movements were in the order of 1 to $2 \mathrm{~km}$ for males and 100 to $200 \mathrm{~m}$ for females (Fig. 1, Table 2). When data for all lobsters captured within the reserve were examined (not just tagged individuals), clear seasonal depthrelated patterns in abundance were evident (Fig. 2). Maximum catch per unit effort (CPUE; individuals per pot lift) of males $<70 \mathrm{~mm}$ tail width occurred at depths of around $20 \mathrm{~m}$ during the summer months, but at depths $<10 \mathrm{~m}$ during the winter. Large males (>70 mm) and females displayed no clear seasonal patterns, with little recorded movement or changes in depth between captures of tagged individuals.

Of the 1114 total recorded lobster movements, 1097 $(98.5 \%)$ took place within a reef, with only $17(1.5 \%)$ involving movements between 2 reefs (Fig. 3). Of the 921 lobsters tagged within the reserve that were recaptured at least once, 49 individuals (48 males, $55.8 \pm 5.4 \mathrm{~mm}$; and 1 female of unknown size) or $5.3 \%$

Table 2. Jasus edwardsii. Median and range of distances moved between recapture events for lobsters tagged within Te Tapuwae o Rongokako Marine Reserve

\begin{tabular}{|lccc|}
\hline Sex & $\begin{array}{c}\text { Tail width } \\
(\mathrm{mm})\end{array}$ & $\begin{array}{c}\text { Median } \\
\text { distance }(\mathrm{m})\end{array}$ & $\begin{array}{c}\text { Range in distance } \\
\text { moved }(\mathrm{m})\end{array}$ \\
\hline Male & $54-59.9$ & 105 & $0-4510$ \\
& $60-69.9$ & 126 & $1-4475$ \\
& $>70$ & 202 & $13-1363$ \\
Female & $54-59.9$ & 35 & $4-1034$ \\
& $60-69.9$ & 45 & $4-1291$ \\
\hline
\end{tabular}



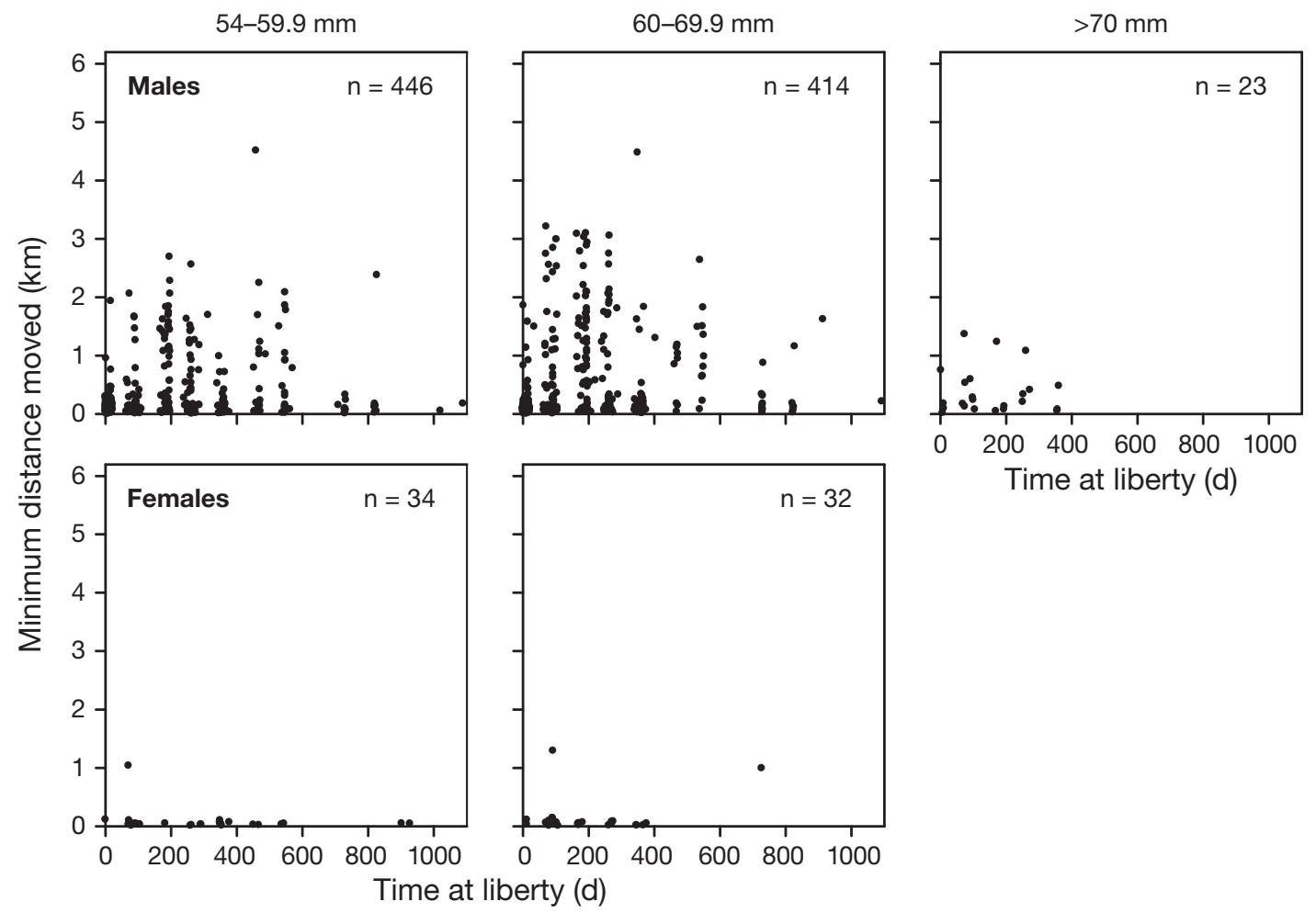

Fig. 1. Jasus edwardsii. Distance moved versus time at liberty for tagged spiny lobster in Te Tapuwae o Rongokako Marine Reserve, New Zealand. Sizes are tail widths
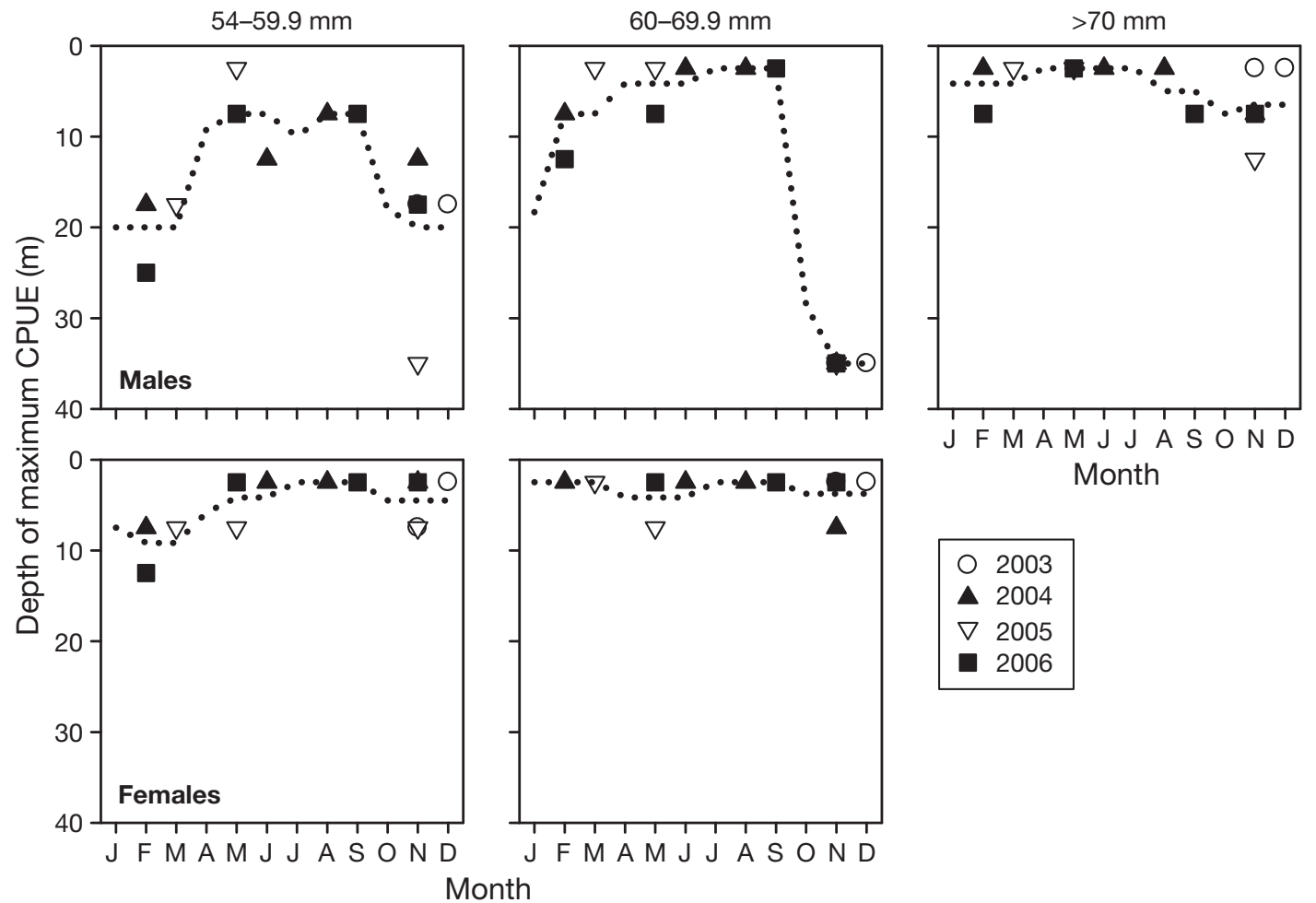

Fig. 2. Jasus edwardsii. Seasonal changes in depth of maximum catch per unit effort (CPUE) (individuals per pot lift, standardsized pots only) for the spiny lobster in Te Tapuwae o Rongokako Marine Reserve, New Zealand. Depth strata were $5 \mathrm{~m}$ wide from 0-20 m, and $10 \mathrm{~m}$ wide from 20-50 m. Sizes are tail widths. Females $>70 \mathrm{~mm}$ tail width are not plotted, as only 1 individual was caught. Dotted lines are 3 mo running averages 

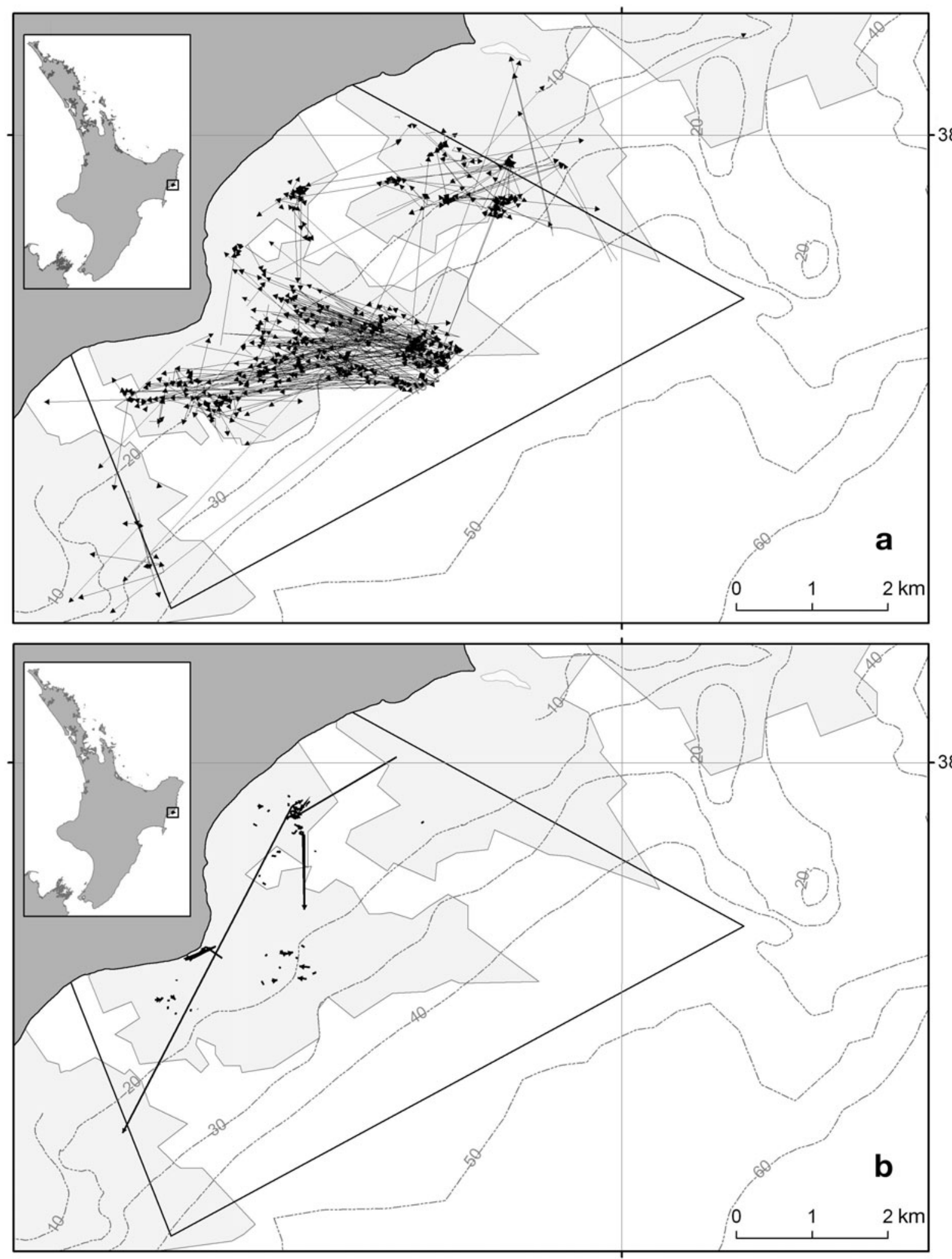

Fig. 3. Jasus edwardsii. Movements of spiny lobsters tagged within Te Tapuwae o Rongokako Marine Reserve, New Zealand. Movements of all tagged male (a) and female (b) individuals that were recaptured at least once are plotted. The marine reserve boundary is indicated by the black-lined polygon bounded on one side by the coastline. Isobaths are depths in metres. The light grey shaded areas indicate the 4 rocky reefs within the survey area (from south to north: Turihaua, Pariokonohi, Whangara, B5) 
were recaptured outside the reserve. The remainder (790 males and 82 females) were only ever recaptured within the marine reserve.

The rate of emigration from each reef within the reserve decreased steadily as the proportion of reef that was protected within the reserve increased (Fig. 4a). Only $1 \%$ of the lobsters tagged on the completely protected Pariokonohi Reef were recaptured outside the marine reserve, versus $29 \%$ of individuals tagged on the protected part of Turihaua Reef, of which only $9 \%$ is within the reserve. The average densities (CPUE from potting) of lobsters on the protected parts of reefs were strongly positively correlated with the proportion of reef protected, being 8-fold higher on Pariokonohi Reef than Turihaua Reef (Fig. 4b). Body size was also positively correlated with the proportion of reef protected (Fig. 4c).

Average densities of legal-sized lobsters tended to be highest in the centre of the marine reserve, declined towards the northern and southern reserve boundaries, and were very low outside the reserve (Fig. 5a,b). The average size of legal males showed a similar pattern (Fig. 5c,d). Within the reserve, densities and average sizes tended to be greater on the fully protected Pariokonohi Reef than on the partially protected reefs where they were similar distances from the reserve boundaries, a pattern particularly apparent for male sizes near the northern boundary
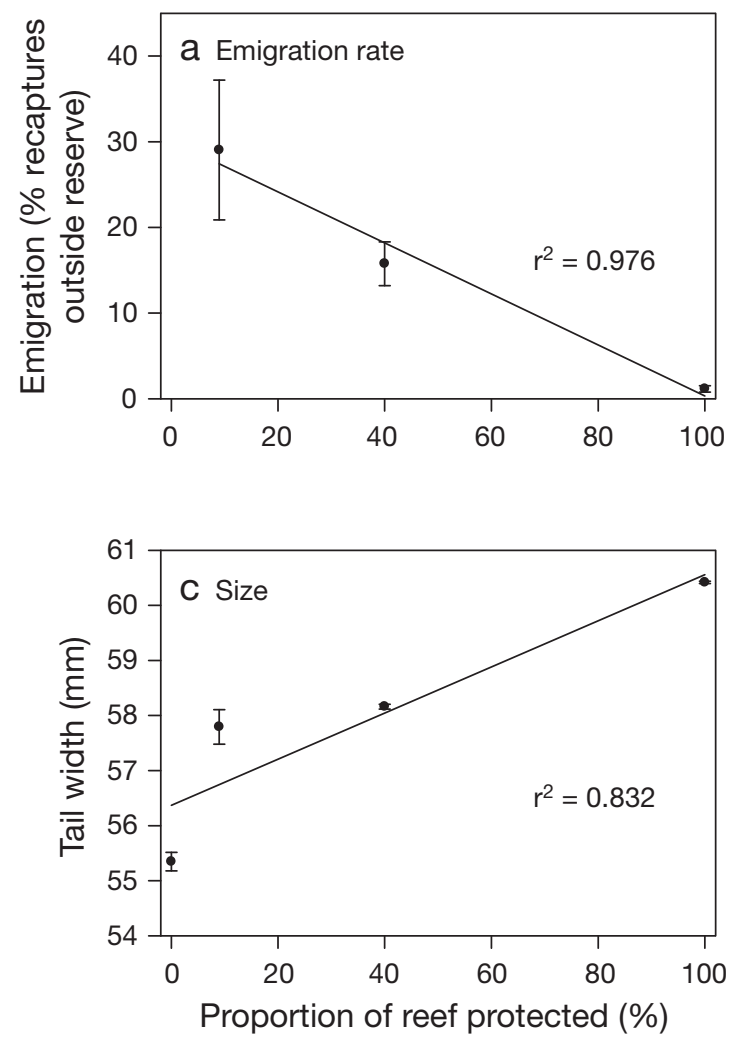

(Fig. 5c). On Turihaua Reef, densities and mean sizes on the protected portion were similar to those on the fished portion. Data on the size or abundance of legal-sized females could not be presented as too few were captured (either within or outside the reserve) to enable analysis of spatial patterns. Only 29 out of 1421 females caught outside the reserve were of legal size.

Large lobsters had a particularly high rate of tag loss, with more than $50 \%$ of recaptured tagged male lobsters over $60 \mathrm{~mm}$ tail width losing their tags (either due to breakage or complete removal) prior to recapture within the 3 yr study period (Table 3 ). The overall rate of tag loss per year varied as the number of tagged animals in the water changed (due to new tag releases, migration and removal of tagged animals by the fishery), but for males it ranged between $9 \%$ for 2003 and $69 \%$ for 2005 (percentage of all recaptured male lobsters that had lost their tags). Rates of tag loss could not be estimated for females because many were not pleopod-clipped (so as not to affect aeration and protection of eggs). It was not possible to correct for tag loss when estimating movement rates, because we could not determine whether pleopod-clipped individuals with missing tags had originally come from inside or outside the marine reserve (more than 2000 individuals were tagged outside the reserve at the same time as part of a broader study).

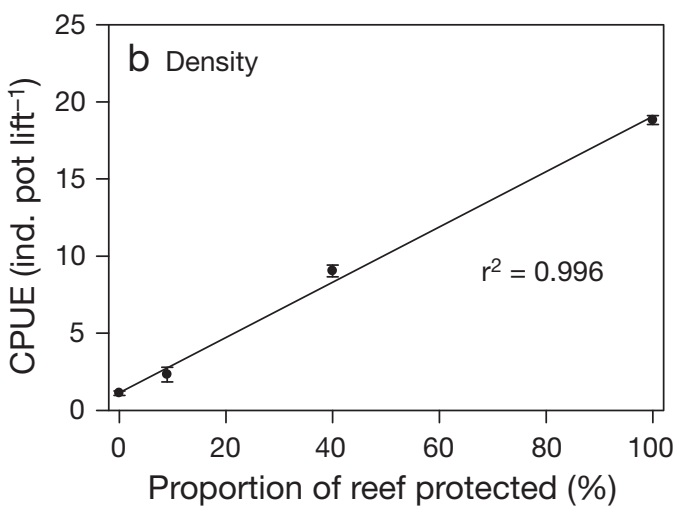

Fig. 4. Jasus edwardsii. Relationships between the proportion of rocky reefs protected within Te Tapuwae o Rongokako Marine Reserve and (a) spiny lobster emigration rates, (b) CPUE (standardsized pots only, all data pooled), and (c) sizes (standard- and three-quarter-sized $52 \mathrm{~mm}$ mesh pots combined) within the reserve. Emigration rate is the percentage of lobsters tagged on the protected portion of a given reef that were later recaptured outside the reserve (of all lobsters from that portion of reef that were recaptured). Data from 4 reefs are presented: $0 \%$ coverage, B5 Reef; 9\%, Turihaua Reef; $40 \%$, Whangara Reef; $100 \%$, Pariokonohi Reef. Regressions are run on averages. Error bars: $\pm \mathrm{SE}$ 

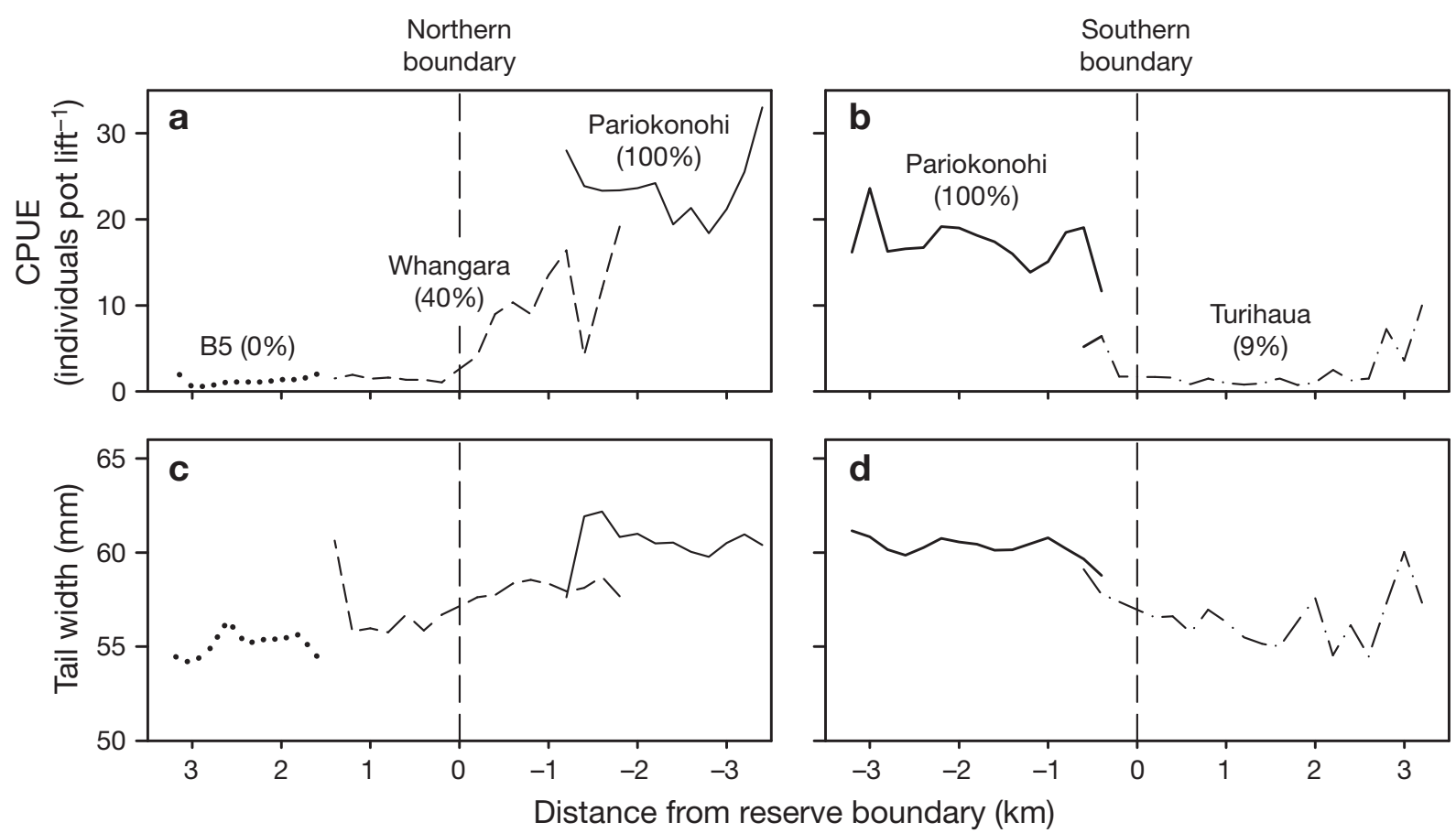

Fig. 5. Jasus edwardsii. Average CPUE (number of legal-sized lobsters per pot, all standard-sized pots) and size of legal male spiny lobster (standard- and three-quarter-sized $52 \mathrm{~mm}$ mesh pots combined) as a function of distance (in $200 \mathrm{~m}$ increments) from the reserve boundary for each of 4 reefs in and adjacent to Te Tapuwae o Rongokako Marine Reserve. Percentages in parentheses next to reef names refer to the proportion of reef protected within the reserve. Negative values on the $x$-axes are within the reserve, positive values outside. Symbols have been omitted for clarity

Table 3. Jasus edwardsii. Tag loss (either removed completely or broken along the tag shaft) in tagged male lobsters recaptured within Te Tapuwae o Rongokako Marine Reserve over 4 calendar years. Note that the initial tag and release location of individuals with lost tags could not be determined. Shown are the percentage tag loss for each size category and total number of recaptured tagged individuals

\begin{tabular}{|lrrrrrrrr|}
\hline $\begin{array}{l}\text { Tail width } \\
(\mathrm{mm})\end{array}$ & \multicolumn{2}{c}{2003} & \multicolumn{2}{c}{2004} & \multicolumn{2}{c|}{2005} & \multicolumn{2}{c|}{2006} \\
& $\%$ & $\mathrm{n}$ & $\%$ & $\mathrm{n}$ & $\%$ & $\mathrm{n}$ & $\%$ & $\mathrm{n}$ \\
\hline$<54$ & 2 & 48 & 30 & 47 & 58 & 19 & 25 & 28 \\
$54-59.9$ & 8 & 153 & 32 & 249 & 62 & 168 & 55 & 146 \\
$60-69.9$ & 11 & 110 & 37 & 304 & 75 & 228 & 71 & 229 \\
$>70$ & 0 & 3 & 0 & 13 & 75 & 4 & 30 & 10 \\
Total & 9 & 318 & 34 & 614 & 69 & 420 & 61 & 414 \\
\hline
\end{tabular}

\section{DISCUSSION}

Recorded movements of tagged lobsters were mostly in the order of 1 to $2 \mathrm{~km}$ for males, and 100 to $200 \mathrm{~m}$ for females, which is consistent with the lack of long-distance movement reported in this region of New Zealand by Booth (1997). Movement had a strong seasonal depth component for male lobsters $<70 \mathrm{~mm}$ tail width, but there was no apparent seasonal depth trend in males $>70 \mathrm{~mm}$ tail width and females of all sizes, which had
CPUE maxima in mostly $<10 \mathrm{~m}$ water depth year-round. These seasonal changes in distribution are consistent with the migrations described in northeastern New Zealand associated with mating, moulting and feeding (MacDiarmid 1991, Kelly et al. 1999). In northeastern New Zealand, male lobsters have been shown to move predominantly offshore during summer and winter subsequent to moulting and mating respectively, and females predominantly offshore prior to larval hatching. However, in contrast to these studies, we observed no offshore movement by males during winter and little movement of tagged females, but it is possible that seasonal variation in catchability influenced the movement patterns observed in our study (Ziegler et al. 2002). For example, pots located within the marine reserve were often full of large male lobsters, which may have excluded females and small males through behavioural interactions. It has been shown that for Jasus edwardsii, there is a dominance hierarchy based on body size and large male lobsters reduce the entrapment of smaller lobsters through behavioural interactions (Frusher \& Hoenig $2001 b)$. It is also possible that females were undertaking inshore-offshore migrations (MacDiarmid 1991) but were not attracted to a baited pot during this migratory period. Comparisons of pot survey data with diver survey data within this reserve suggested that pots oversampled males (Freeman 2008). 
Individuals of both sexes were almost invariably $(98.5 \%)$ recaptured on the same reef they were originally collected from and tagged on, indicating a reluctance to cross the soft sediments between reefs. This is consistent with studies from Tasmania (Australia) (Buxton et al. 2006), but not with other studies from northeastern New Zealand, where movement across soft sediment habitats has been reported (Kelly et al. 1999, Langlois et al. 2005). This inconsistency may have been because the muddy sediments at our study site were more difficult for lobsters to traverse or held fewer prey than the sandy sediments at the more northerly study sites of Kelly et al. (1999) and Langlois et al. (2005). Additionally, the reefs we studied extended further offshore and to greater depths than those in previous studies, enabling lobsters to remain on them across a much greater depth range.

The likelihood of a lobster leaving Te Tapuwae o Rongokako Marine Reserve and becoming susceptible to the heavy commercial fishing pressure outside increased linearly as the proportion of its reef that was unprotected increased. Within the reserve, lobster densities and average sizes of lobsters were negatively correlated with the proportion of reef extending outside the reserve, consistent with a substantial loss of emigrants to fishing. The trend in size of lobsters is likely due to a combination of selection for larger lobsters in the fishery outside the reserve and the more sedentary habits of larger male lobsters within the reserve. Although the 3 reefs inside the reserve appeared to have similar physical characteristics and associated organisms, the reef that was $100 \%$ protected contained 8-fold higher lobster densities than the protected part of the reef that was $91 \%$ unprotected.

Although the fully-protected reef contributes few adult lobsters to the surrounding fishery, it probably benefits the fishery on a larger scale by exporting significant quantities of larvae due to the abundance and large size of the resident adult lobsters. For example, in 1995 egg production by lobsters in the Cape Rodney to Okakari Point Marine Reserve (northeast New Zealand) was 11 and 22 times higher per unit area than in 2 nearby fished areas (A. B. MacDiarmid unpubl. data).

The increased likelihood that habitat patches will cross reserve boundaries with increasing distance from the centre of the reserve is likely a major mechanism behind the distance-to-boundary patterns reported for many species, whereby densities and average sizes of fished animals are higher in the centre of reserves than at the edges (Edgar \& Barrett 1999, Babcock et al. 2007). This pattern is usually attributed to likelihood of movement across the boundaries without invoking habitat features. It could be argued that the habitat-configuration-based explanation for the patterns described in this study is an unnecessary complication to the simpler distance-toboundary explanation, which is independent of habitat structure. In our study a confounding factor is that Pariokonohi Reef was both the reef in the centre of the reserve and the only reef completely protected within the reserve. However, the simpler distance-toboundary alternative would not account for why lobster densities and, especially, average sizes of male lobsters were higher on the $100 \%$ protected Pariokonohi Reef than on the $40 \%$ protected Whangara Reef in the region where the 2 reefs were similar distances from the reserve's northern boundary (1 to $2 \mathrm{~km}$ ). Moreover, our explanation is consistent with the documented reluctance of lobsters to leave reefs at our study site and the observed rates of emigration from the protected part of each reef into the adjacent fishery. It would be useful to conduct further research in a reserve where the most protected reef lay near a boundary. In addition, analysis of the movement patterns of lobsters tagged outside Te Tapuwae o Rongokako Marine Reserve, in conjunction with those tagged within, may allow an estimation of the net movement of lobster biomass across the boundaries of this reserve.

\section{CONCLUSIONS}

The optimal design of a marine reserve depends on the management objectives. If the aim is to conserve 'natural' biological communities, then the reserve boundaries should follow barriers to species movement (e.g. muddy sediments in the case of Jasus edwardsii). If export of individuals associated with certain habitat is desired, then reserve boundaries should intersect that habitat. Our study system, the Te Tapuwae o Rongokako Marine Reserve, achieves both aims, albeit unintentionally, by (1) protecting an entire large reef on which lobsters have become large and abundant, and (2) facilitating the movement of lobsters from the reserve into the surrounding fishery where the reserve boundaries cross continuous rocky reef habitat.

Acknowledgements. Field work was undertaken with the assistance of staff from the Department of Conservation and of commercial fishermen from Gisborne, New Zealand. This research was funded by the Department of Conservation, through core funding and via the Cross-Departmental Contestable Research Pool project 'Maori Methods and Indicators for Marine Protection' (Research Investigation Number 3335). Our research was conducted under Ministry of Fisheries Special Permits NN0205 and 335, and Department of Conservation Animal Ethics Committee Approval AEC92. We thank the reviewers for their constructive comments. 


\section{LITERATURE CITED}

Abesamis RA, Russ GR (2005) Density-dependent spillover from a marine reserve: long-term evidence. Ecol Monogr 15:1798-1812

Annala JH, Bycroft BL (1993) Movements of rock lobsters (Jasus edwardsii) tagged in Fiordland, New Zealand. NZ J Mar Freshw Res 27:183-190

Babcock RC, Kelly S, Shears NT, Walker JW, Willis TJ (1999) Changes in community structure in temperate marine reserves. Mar Ecol Prog Ser 189:125-134

Babcock RC, Phillips JC, Lourey M, Clapin G (2007) Increased density, biomass and egg production in an unfished population of Western Rock Lobster (Panulirus cygnus) at Rottnest Island, Western Australia. Mar Freshw Res 58:286-292

Booth JD (1997) Long-distance movements in Jasus spp. and their role in larval recruitment. Bull Mar Sci 61:111-128

Buxton C, Barrett N, Haddon M, Gardner C, Edgar G (2006) Evaluating the effectiveness of marine protected areas as a fisheries management tool. Tasmanian Aquaculture and Fisheries Institute, Hobart

Davis GE, Dodrill JW (1989) Recreational fishery and population dynamics of spiny lobsters, Panulirus argus, in Florida Bay, Everglades National Park, 1977-1980. Bull Mar Sci 44: $78-88$

Edgar GJ, Barrett NS (1999) Effects of the declaration of marine reserves on Tasmanian reef fishes, invertebrates and plants. J Exp Mar Biol Ecol 242:107-144

Forcada A, Valle C, Bonhomme P, Criquet G, Cadiou G, Lenfant P, Sánchez-Lizaso JL (2009) Effects of habitat on spillover from marine protected areas to artisanal fisheries. Mar Ecol Prog Ser 379:197-211

Freeman DJ (2008) The ecology of spiny lobsters (Jasus edwardsii) on fished and unfished reefs. PhD thesis, University of Auckland

Frusher SD, Hoenig JM (2001a) Estimating natural and fishing mortality and tag reporting rate of southern rock lobster (Jasus edwardsii) from a multiyear tagging model. Can J Fish Aquat Sci 58:2490-2501

Frusher SD, Hoenig JM (2001b) Impact of lobster size on selectivity of traps for southern rock lobster (Jasus edwardsii). Can J Fish Aquat Sci 58:2482-2489

Gardner C, Frusher S, Haddon M, Buxton C (2003) Movements of the southern rock lobster Jasus edwardsii in Tasmania, Australia. Bull Mar Sci 73:653-671

Haist V, Breen PA, Kim SW, Starr PJ (2005) Stock assessment of red rock lobsters (Jasus edwardsii) in CRA3 in 2004. New Zealand Fisheries Assessment Report 2005/38, Ministry of Fisheries, Wellington

Halpern BS, Warner RR (2003) Matching marine reserve design to reserve objectives. Proc R Soc London B Biol 270:1871-1878

Hilborn R (1990) Determination of fish movement patterns from tag recoveries using maximum likelihood estimators. Can J Fish Aquat Sci 47:635-643

Editorial responsibility: Lisandro Benedetti-Cecchi, Pisa, Italy
Jennings S (2000) Patterns and prediction of population recovery in marine reserves. Rev Fish Biol Fish 10: 209-231

Kelly S (2001) Temporal variation in the movement of the spiny lobster Jasus edwardsii. Mar Freshw Res 52: 323-331

Kelly S, MacDiarmid AB (2003) Movement patterns of mature spiny lobsters, Jasus edwardsii, from a marine reserve. NZ J Mar Freshw Res 37:149-158

Kelly S, MacDiarmid AB, Babcock RC (1999) Characteristics of spiny lobster, Jasus edwardsii, aggregations in exposed reef and sandy areas. Mar Freshw Res 50: 409-416

$>$ Kelly S, Scott D, MacDiarmid AB, Babcock RC (2000) Spiny lobster, Jasus edwardsii, recovery in New Zealand marine reserves. Biol Conserv 92:359-369

- Kramer DL, Chapman MR (1999) Implications of fish home range size and relocation for marine reserve function. Environ Biol Fishes 55:65-79

Langlois TJ, Anderson MJ, Babcock RC (2005) Reef-associated predators influence adjacent soft-sediment communities. Ecology 86:1508-1519

> MacDiarmid AB (1991) Seasonal changes in depth distribution, sex ratio and size frequency of spiny lobster Jasus edwardsii on a coastal reef in northern New Zealand. Mar Ecol Prog Ser 70:129-141

MacDiarmid AB, Hickey B, Maller RA (1991) Daily movement patterns of the spiny lobster Jasus edwardsii (Hutton) on a shallow reef in northern New Zealand. J Exp Mar Biol Ecol 147:185-205

Rowe S (2001) Movement and harvesting mortality of American lobsters (Homarus americanus) tagged inside and outside no-take reserves in Bonavista Bay, Newfoundland. Can J Fish Aquat Sci 58:1336-1346

> Shears NT, Babcock RC (2002) Marine reserves demonstrate top-down control of community structure on temperate reefs. Oecologia 132:131-142

Shears NT, Babcock RC (2004) Indirect effects of marine reserve protection on New Zealand's rocky coastal marine communities. Science Internal Series 192, Department of Conservation, Wellington

> Tewfik A, Bene C (2003) Effects of natural barriers on the spillover of a marine mollusc: implications for fisheries reserves. Aquat Conserv: Mar Freshw Ecosyst 13: 473-488

Topping DT, Lowe CG, Caselle JE (2005) Home range and habitat utilization of adult California sheephead Semicossyphus pulcher (Labridae), in a temperate no-take marine reserve. Mar Biol 147:301-311

Tupper MH (2007) Spillover of commercially valuable reef fishes from marine protected areas in Guam, Micronesia. Fish Bull (Wash DC) 105:527-537

Wilson C, Freeman D, Hogan K, Thompson K (2007) Maori methods and indicators for marine protection: summary of research findings, Ngati Kere, Ngati Konohi, Ministry for the Environment, Department of Conservation, Wellington

Ziegler PE, Frusher SD, Johnson CR, Gardner C (2002) Catchability of the southern rock lobster Jasus edwardsii, I. Effects of sex, season and catch history. Mar Freshw Res 53:1143-1148

Submitted: February 27, 2009; Accepted: May 22, 2009

Proofs received from author(s): July 28, 2009 